\title{
Reduction of the survival time of pig xenotransplants by porcine cytomegalovirus
}

\author{
Joachim Denner(1)
}

\begin{abstract}
Background: Xenotransplantation using pig cells, tissues and organs may help to overcome the shortage of human tissues and organs for the treatment of tissue and organ failure. Progress in the prevention of immunological rejection using genetically modified pigs and new, more effective, immunosuppression regimens will allow clinical application of xenotransplantation in near future. However, xenotransplantation may be associated with the transmission of potentially zoonotic porcine microorganisms. Until now the only xenotransplantationassociated transmission was the transmission of the porcine cytomegalovirus (PCMV) into non-human primates. PCMV caused a significant reduction of the survival time of the pig transplant.

Main body of the abstract: Here the available publications were analysed in order to establish the mechanism how PCMV shortened the survival time of xenotransplants. PCMV is a herpesvirus related to the human cytomegalovirus and the human herpesviruses 6 and 7. These three human herpesviruses can cause serious disease among immunocompromised human individuals, including transplant recipients. It was shown that PCMV predominantly contributes to the reduction of transplant survival in non-human primates by disruption of the coagulation system and by suppression and exhaustion of the immune system.

Conclusion: Although it is still unknown whether PCMV infects primate cells including human cells, indirect mechanism of the virus infection may cause reduction of the xenotransplant survival in future clinical trials and therefore PCMV has to be eliminated from donor pigs.
\end{abstract}

Keywords: Porcine cytomegalovirus, Xenotransplantation, Herpesviruses

\section{Background}

In the last years, a significant progress was achieved in the development of xenotransplantation [1-4]. The main achievements were the generation of pigs with multiple genetic modifications [5-7] and new, more efficient immunosuppression regimens $[8,9]$, allowing to overcome the hyperacute rejection as well as other immunological reactions. Increased survival times of different pig transplants in non-human primates demonstrated the impressive progress made in the field (Table 1) [3, 8-17]. However, immunological rejection and physiological incompatibility are only two hurdles on the way to the clinical application of xenotransplantation. Another hurdle

Correspondence: DennerJ@rki.de

Robert Koch Fellow, Robert Koch Institute, Nordufer 20, 13353 Berlin, Germany

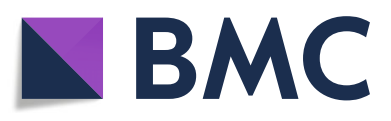

is the risk to transmit porcine microorganisms to the recipient which may induce severe disease (zoonosis or xenosis). Microorganisms include bacteria, protozoa, fungi and viruses. In this context viruses are certainly the most harmful microorganisms due to the lack of effective antivirals and vaccines. Among the porcine viruses of interest are DNA viruses such as PCMV, the porcine circoviruses 1,2 and 3 (PCV1, PCV2, PCV3), and the porcine lymphotropic herpesviruses (PLHV-1, PLHV-2, PLHV-3) as well as RNA viruses such as the hepatitis E virus (HEV), the porcine reproductive and respiratory syndrome virus (PRRSV) and the Nipah virus (NIV) (for reviews discussing each virus type in the context of xenotransplantation see [18-25]). Some of these viruses, e.g. PCV2, PRRSV and NIV, cause severe disease in the infected pigs and can easily be detected. For the detection of the viruses not causing diseases in the infected pigs sensitive screening methods

(c) The Author(s). 2018 Open Access This article is distributed under the terms of the Creative Commons Attribution 4.0 International License (http://creativecommons.org/licenses/by/4.0/), which permits unrestricted use, distribution, and reproduction in any medium, provided you give appropriate credit to the original author(s) and the source, provide a link to the Creative Commons license, and indicate if changes were made. The Creative Commons Public Domain Dedication waiver (http://creativecommons.org/publicdomain/zero/1.0/) applies to the data made available in this article, unless otherwise stated. 
Table 1 Survival time of different porcine xenotransplants in non-human primates

\begin{tabular}{lll}
\hline Pig transplant & $\begin{array}{l}\text { Longest survival } \\
\text { time (days) }\end{array}$ & Reference \\
\hline Islet cells & 950 & Shin et al., [10] \\
Hearts, heterotopic & 945 & Mohiuddin et al., [8] \\
Hearts, orthotopic & 57 & Byrne et al., [1 1] \\
Kidney & 499 & $\begin{array}{l}\text { Higginbotham et al., [9], } \\
\text { Iwase et al., [12, 13], } \\
\end{array}$ \\
& & Wang et al., [3], \\
& 549 & Kim et al., [17] \\
Neurones & Badin et al., [14] \\
Cornea & 511 & Kim et al., [15] \\
Liver & 29 & Wang et al., [3] \\
Lung & 10 & Watanabe et al., [16]
\end{tabular}

are required. Among the viruses with potential zoonotic potential are also the porcine endogenous retroviruses (PERVs) which are integrated in the genome of all pigs and which - in contrast to all other porcine viruses, bacteria and fungi - cannot be eliminated by selection of negative animals, vaccination, treatment, early weaning, colostrum deprivation, Caesarean delivery or embryo transfer [26]. This manuscript will concentrate on the mechanism how PCMV contributes to the reduction of transplant survival.

\section{Main text}

\section{Risk evaluation of some porcine viruses}

Viruses affecting the health of the donor pigs will harm the transplant and have to be eliminated. For some of these viruses effective vaccines exist, which prevent the infection or at least the outbreak of the disease. More difficult is the situation with viruses not affecting the health of the donor pigs. With two exceptions we do not know whether transmission of these viruses will harm the transplant recipient. On exception is HEV. It was shown that HEV can be transmitted to humans by undercooked meat or contact and that infection of immune-compromised humans leads to a chronic HEV infection, whereas infection of individuals with pre-existing liver disease may be fatal $[20,21]$. There are no licensed vaccines or effective antivirals against HEV. The other, more important exception, is PCMV, which will be discussed in the next chapter.

The risk posed by PERV is difficult to evaluate. Retroviruses are known to induce tumours and / or immunodeficiency in the infected individuals. Until now, no transmission of PERV was observed in numerous pig to non-human primate xenotransplantations and in first clinical trials in humans [26, 27]. If recent reports, demonstrating inactivation of all PERVs in pig cells [28] and in live animals [29] by gene editing using clustered regularly interspaced short palindromic repeats/ CRISPR associated (CRISPR/Cas), can be confirmed, the risk posed by PERV will be eliminated [30].

\section{Special case: PCMV}

PCMV is an enveloped DNA virus belonging to the family Herpesviridae, subfamily Betaherpesvirinae, genus Roseolovirus [31]. PCMV is found in the tissues throughout the body including the nose of infected newborn piglets where it causes rhinitis and conjunctivitis. Most infections are sub-clinical, clinical disease is rare [32]. Clinical signs are only seen if PCMV infects a sow for the first time when she is late in pregnancy. Foetal deaths, mummified foetuses, stillbirths, and weak piglets are observed. The virus is shed in discharges from the nose and eyes, urine and farrowing fluids, it is also transmitted via the boar through semen and crosses the placenta to infect piglets before birth [32-34].

Despite the similar name, PCMV is more closely related with human herpesvirus-6 (HHV-6) and HHV-7, which are also Roseoloviruses, but not so closely with the human cytomegalovirus (HCMV), also called HHV-5 [31, 35, 36]. HCMV is the cause of disease in the human fetus, the allograft recipient, AIDS patient, those admitted to intensive care units, and in the elderly [37]. HCMV is the single most important infectious agent affecting recipients of organ transplants, with at least two-thirds of these patients having CMV infection after transplantation [38]. During solid organ transplantation, seropositive donors frequently transmit HCMV to seronegative recipients (primary infection) [38, 39]. Primary infection has the greatest clinical impact. In addition, during allotransplantation HCMV may be re-activated by the allo-immune responses and by the immunosuppression in the HCMV-positive recipient [40]. Finally, superinfections have been described [38]. Pneumonia induced by HCMV is most common after lung and heart/lung transplantations in humans [41, 42], however, the spectrum of CMV pneumonia has changed with the introduction of routine antiviral prophylaxis [43-45]. Consumptive coagulopathy (CC) and thrombotic microangiopathy have been described in disseminated HCMV infection in humans [43, 44]. The thrombotic microangiopathy can be treated by ganciclovir. HCMV produces overt disease only if the viral load increases to high levels. Due to a robust immune response the infected individual usually remains asymptomatic. However, this permanent control of HCMV impairs the immune system and leads to immunosuppression [37]. HCMV carry in its genome the viral gene UL111A, which encodes a viral IL-10 which is homoloque to the cellular IL-10, a well-known immunosuppressive cytokine [45]. This protein is also expressed in healthy HCMV-positive donors and may play a key role in sensing or modifying the host environment during latency [46].

As mentioned, the human roseoloviruses HHV-6A, HHV-6B and HHV-7 are more closely related with PCMV, even cross-reacting antibodies have been observed in humans [47]. HHV-6A, HHV-6B and HHV-7 
are widely distributed in the human population. Like other herpesviruses, these viruses cause acute infection, establish latency, and in the case of HHV-6A and HHV-6B, whole virus can integrate into the host chromosome [48]. Primary infection with HHV-6B occurs in nearly all children and was first linked to the clinical syndrome roseola infantum. However, roseolovirus infection results in a spectrum of clinical disease, ranging from asymptomatic infection to acute febrile illnesses with severe neurologic complications. Generally, reactivation of roseoloviruses has been associated with various clinical syndromes including fever, encephalitis, pneumonitis, hepatitis, bone marrow suppression, and a graft versus host disease (GVHD)-like rash, however co-infection with other viruses including HCMV cannot be excluded [49]. HHV-6 and HHV-7 are together with HCMV common infections in transplant recipients and have been clearly associated with early transplant rejection [38, 50-53].

\section{Reduction of transplant survival time in non-human primates by PCMV}

PCMV is the first virus with proven pathogenicity in xenotransplantation. In numerous preclinical trials transplanting pig organs into non-human primates, a significant reduction of the survival time was observed (Table 2) [54-60]. Transplantation of PCMV-positive thymokidneys into baboons resulted in an increased PCMV titre, hematuria, systemic coagulopathy and a reduced survival time of the pig xenotransplant [54].

Transplanting pig kidneys into baboons, the first kidney coming from a PCMV-positive animal failed after 13 days and a second kidney from a PCMV-negative animal was transplanted after excision of the first kidney. The second transplant survived for 60 days without hemorrhagic changes, clearly demonstrating the PCMV infection was the reason of the short survival time of the first transplant [58].

Transmission of PCMV was also observed in orthotopic pig heart transplantations in baboons [61, 62]. PCMV-positive cells were found disseminated in the baboon recipient, it seemed likely that these are PCMV-infected pig cells [63]. The influence on the survival time in this setting is still unclear. In this case, replication in the xenotransplant, the pig heart, should be sufficient to generate a high virus load in the blood of the baboon.

\section{Are herpesviruses species-specific?}

At present it is still unclear, whether PCMV can infect human and non-human primate cells. There is one report showing infection of human cells [64] and another not showing infection [65]. Ever since their first isolation, cytomegaloviruses have been recognized as being highly species specific, replicating only in cells of their own or a closely related host species, while cells of phylogenetically more distant hosts are usually not permissive for viral replication. For instance, HCMV replicates in human and chimpanzee fibroblasts but not in rodent cells, and murine cytomegalovirus (MCMV) replicates in cells of mice and rats but not in primate cells [66]. However, MCMV can be adapted stepwise to mutate and replicate in cultured human cells [66]. Because a single gene of the HCMV encoding a mitochondrial inhibitor of apoptosis is sufficient to allow MCMV replication in human cells, induction of apoptosis was thought to serve as an innate immune defence to inhibit cross-species infections of rodent CMVs [67]. MCMV is also thought to be a species-specific virus, however a recombinant MCMV entered and expressed reporter genes in both rat and human brain cells [68]. These data show that under certain conditions cytomegaloviruses may mutate and replicate in other species. In the case of the mutated MCMV able to replicate in human cells only a limited number of mutations was detected [66]. When analysing PCMV in baboons which received a PCMV-infected pig heart, low numbers of PCMV-positive cells were found in all organs of the baboon, suggesting that disseminated pig cells produce the virus found in the blood [63].

Another example for transspecies transmission of a herpesvirus is the baboon cytomegalovirus (BaCMV). This virus was shown to infect human cell in vitro [69]. Furthermore, BaCMV was found in a human recipient after transplantation of a baboon liver and BaCMV able to replicate on human cells was isolated from the patient [70]. Meanwhile it was also shown that HCMV infects pig cells [71].

\section{Possible mechanisms how PCMV causes reduction of the transplant survival time}

Since several reviews concerning the role of PCMV in xenotransplantation have been published [18, 19, 22, 72], here mainly the mechanisms leading to a reduced survival will be put into focus and analysed in more details (see Table 2). There are two main mechanisms: First, the influence on the coagulation system, and, second, the influence on the immune system of the infected animal.

Consumptive coagulopathy (CC) defined by thrombocytopenia, decreasing fibrinogen, and haemorrhage, has been observed in pig to non-human primate xenotransplantations [73-75]. Infections with other herpesviruses have also been shown to directly activate prothrombin and initiate clotting [76, 77]. In vitro activation of the porcine tissue factor (TF) by PCMV infection of porcine aortic endothelial cells (PAEC) was reported, although in vivo no correlation between TF activation and PCMV infection was observed [55]. When 


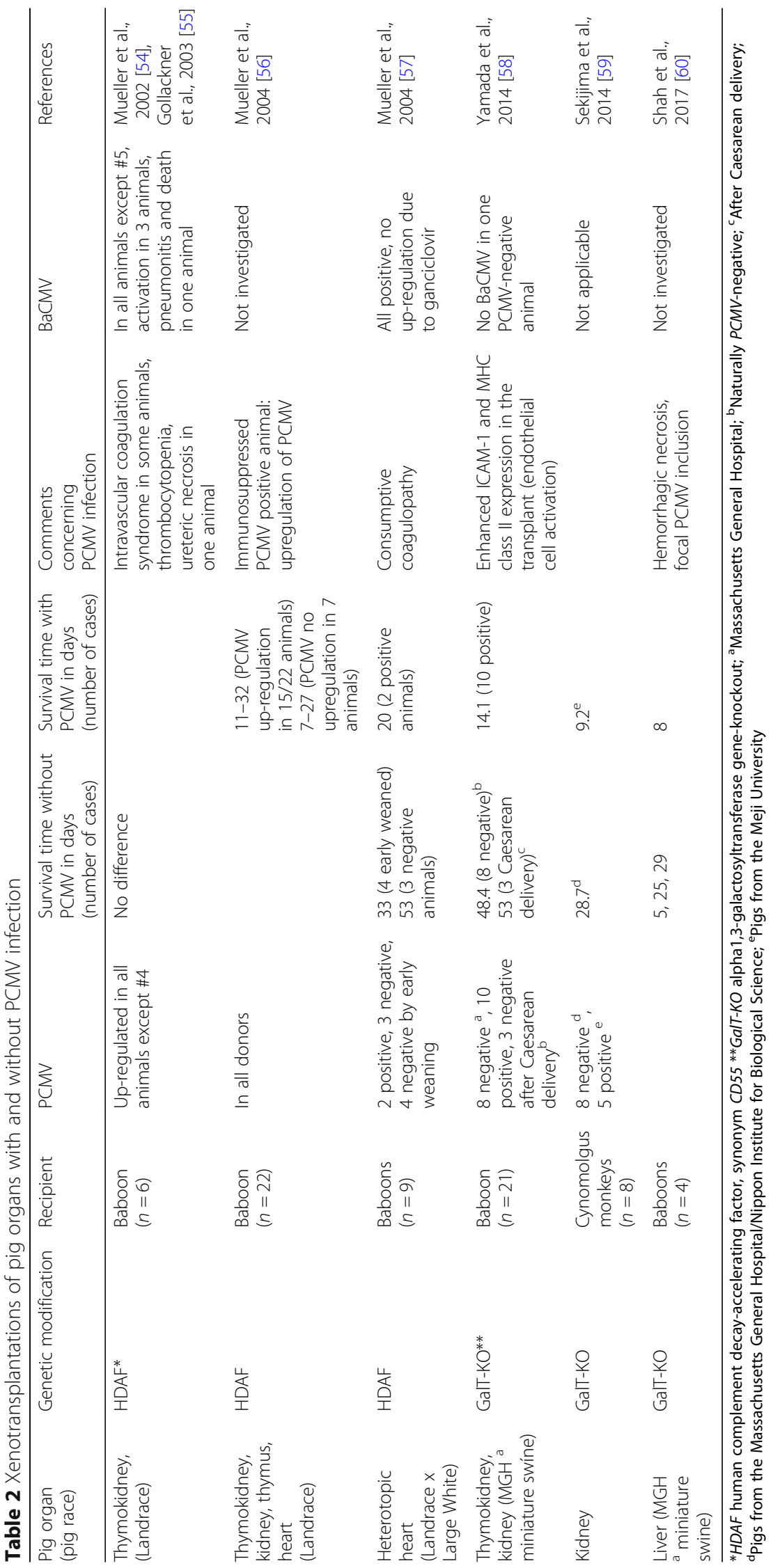


pig kidneys were transplanted into baboons, an enhanced intercellular adhesion molecule 1 (ICAM-1) expression was observed in the transplant (endothelial cell activation) [58]. This reminds the situation with HCMV. After in vitro infection of HUVEC (human umbilical vein endothelial cells) with HCMV also an enhanced ICAM-1 expression was observed [78].

PCMV is an immunosuppressive virus modulating the expression of immune-related genes [79]. A PCMV infection in pigs is often associated with opportunistic bacterial infections [35]. Transcriptome analysis of PCMV-infected thymuses showed that numerous immune-regulatory genes were up- or downregulated [80]. When porcine microRNAs (miRNA) were analysed in PCMV-infected and none-infected porcine macrophages, the differentially expressed miRNA were mainly involved in immune and metabolic processes [81].

\section{PCMV and PERVs}

No increased expression of PERV in transplanted pig kidneys from PCMV-positive animals compared with kidneys from uninfected animals was reported [82]. The interaction of PCMV and PERV deserves further investigation, especially in lymphoid tissues. So it was shown that allogenic stimulation [83] or cultivation in culture medium [63] of pig PBMCs significantly enhanced the expression of PCMV. On the other hand, stimulation of pig PBMCs with mitogens induced an enhanced expression of PERV associated with release of virus particles [84-86]. In this context two scenarios are of interest and should be investigated: PERV-expression in PCMV-infected pig immune cells and PERV-expression in pig lymphocytes immune-stimulated by PCMV.

\section{How to prevent PCMV transmission}

Like many of the potentially zoonotic microorganisms, PCMV can be eliminated by selection of PCMV-negative animals or by early weaning. Since PCMV can be transmitted via the placenta, Caesarean section, colostrum deprivation and embryo transfer may be useful. There were some efforts to eliminate PCMV by early weaning [57, 87]. Only recently it was shown that early weaning completely eliminated porcine cytomegalovirus from a newly established facility for pig donors generated for xenotransplantation [88].

Antiviral drugs such as ganciclovir, cidofovir and to a lesser extent the more toxic compounds foscarnet and acyclovir have been shown to inhibit replication of PCMV [89]. However, PCMV - in contrast to the human CMV - is highly resistant to ganciclovir [90]. Unfortunately, vaccines against PCMV are not yet available, although first immunisation experiments with PCMVderived antigens were successful [91].

\section{Conclusion}

PCMV is the first virus with proven pathogenicity in xenotranplantation. In numerous preclinical trials transplanting pig organs into non-human primates, a significant reduction of the survival time was observed when the organs were PCMV-infected. The possible mechanisms of reduction of survival time are based on the disruption of the coagulation system and by suppression and exhaustion of the immune system. Although PCMV is resistant against antivirals which are effective against other herpesviruses and although vaccines against PCMV do not exist, PCMV can easily eliminated by early weaning and isolation of the negative animals.

\section{Abbreviations \\ BaCMV: Baboon cytomegalovirus; CC: Consumptive coagulopathy; CRISPR/ Cas: Clustered regularly interspaced short palindromic repeats/ CRISPR associated; GVHD: Graft versus host disease; HCMV: Human cytomegalovirus; HEV: Hepatitis E virus; HHV-5: Human herpesvirus 5; HHV-6A: Human herpesvirus 6A; HHV-6B: Human herpesvirus 6B; HHV-7: Human herpesvirus 7; ICAM-1: Intercellular adhesion molecule 1; MCMV: Murine cytomegalovirus; NIV: Nipah virus; PERV: Porcine endogenous retroviruses; PCV1: Porcine circovirus 1; PCV2: Porcine circovirus 2; PCV3: Porcine circovirus 3; PLHV-1, PLHV-2, PLHV-3: Porcine lymphotropic herpesviruses 1,2,3; PRRSV: Porcine reproductive and respiratory syndrome virus; TF: Tissue factor}

\section{Acknowledgments}

I would like to thank Prof. Buno Reichart for the suggestion to write this review.

\section{Funding}

This work was supported by the German Science Foundation (Deutsche Forschungsgemeinschaft, TR127).

Availability of data and materials

Not applicable.

\section{Authors' contribution}

$J D$ analysed the literature and wrote the manuscript. The author read and approved the final manuscript.

Authors' information

Dr. Joachim Denner, Robert Koch Institute, Nordufer 20, 13,353 Berlin, Germany.

Ethics approval and consent to participate

Not applicable.

Consent for publication

Not applicable.

Competing interests

The author declares that he has no competing interests.

\section{Publisher's Note}

Springer Nature remains neutral with regard to jurisdictional claims in published maps and institutional affiliations.

Received: 10 July 2018 Accepted: 28 October 2018

Published online: 08 November 2018

\section{References}

1. Cooper DK, Satyananda V, Ekser B, van der Windt DJ, Hara H, Ezzelarab MB, Schuurman HJ. Progress in pig-to-non-human primate transplantation models (1998-2013): a comprehensive review of the literature. Xenotransplantation. 2014;21(5):397-419.

2. Denner J. Recent progress in xenotransplantation, with emphasis on virological safety. Ann Transplant. 2016;21:717-27. 
3. Wang $L$, Cooper DKC, Burdorf L, Wang Y, Iwase $H$. Overcoming coagulation dysregulation in pig solid organ transplantation in non-human primates: recent progress. Transplantation. 2018. https://doi.org/10.1097/TP. 0000000000002171.

4. Meier RPH, Muller YD, Balaphas A, Morel P, Pascual M, Seebach JD, Buhler LH. Xenotransplantation: back to the future? Transpl Int. 2018;31(5):465-77.

5. Niemann $H$, Petersen B. The production of multi-transgenic pigs, update and perspectives for xenotransplantation. Transgenic Res. 2016;25:361-74.

6. Klymiuk N, Aigner B, Brem G, Wolf E. Genetic modification of pigs as organ donors for xenotransplantation. Mol Reprod Dev. 2010;77:209-21.

7. Cooper DK, Ekser B, Ramsoondar J, Phelps C, Ayares D. The role of genetically engineered pigs in xenotransplantation research. J Pathol. 2016;238(2):288-99.

8. Mohiuddin MM, Singh AK, Corcoran PC, Thomas ML 3rd, Clark T, Lewis BG, Hoyt RF, Eckhaus M, Pierson RN 3rd, Belli AJ, Wolf E, Klymiuk N, Phelps C, Reimann KA, Ayares D, Horvath KA. Chimeric 2C10R4 anti-CD40 antibody therapy is critical for long-term survival of GTKO.hCD46.hTBM pig-to-primate cardiac xenograft. Nat Commun. 2016;7:11138.

9. Higginbotham L, Mathews D, Breeden CA, Song M, Farris AB 3rd, Larsen CP, Ford ML, Lutz AJ, Tector M, Newell KA, Tector AJ, Adams AB. Pre-transplant antibody screening and anti-CD154 costimulation blockade promote longterm xenograft survival in a pig-to-primate kidney transplant model. Xenotransplantation. 2015;22(3):221-30.

10. Shin JS, Kim JM, Min BH, Yoon IH, Kim HJ, Kim JS, Kim YH, Kang SJ, Kim J, Kang HJ, Lim DG, Hwang ES, Ha J, Kim SJ, Park WB, Park CG. Pre-clinical results in pig-to-non-human primate islet xenotransplantation using anti-CD40 antibody (2C10R4)-based immunosuppression. Xenotransplantation. 2018 Jan;25(1).

11. Byrne GW, Du Z, Sun Z, Asmann YW, McGregor CG. Changes in cardiac gene expression after pig-to-primate orthotopic xenotransplantation. Xenotransplantation. 2011;18:14e27.

12. Iwase H, Liu H, Wijkstrom M, Zhou H, Singh J, Hara H, Ezzelarab M, Long C, Klein E, Wagner R, Phelps C, Ayares D, Shapiro R, Humar A, Cooper DK. Pig kidney graft survival in a baboon for 136 days: longest life-supporting organ graft survival to date. Xenotransplantation. 2015;22(4):302-9.

13. Iwase H, Hara H, Ezzelarab M, Li T, Zhang Z, Gao B, Liu H, Long C, Wang Y, Cassano A, Klein E, Phelps C, Ayares D, Humar A, Wijkstrom M, Cooper DKC. Immunological and physiological observations in baboons with life-supporting genetically engineered pig kidney grafts. Xenotransplantation. 2017;24(2). https://doi.org/10.1111/xen.12293.

14. Badin RA, Vanhove B, Vadori M, et al. Systemic immunosuppression plus local production of CTLA4-Ig to control rejection of transgenic pig neuroblasts in non-human primates. Xenotransplantation. 2013;20:367.

15. Kim J, Kim DH, Choi HJ, et al. Anti-CD40 antibody-mediated costimulation blockade promotes long-term survival of deep-lamellar porcine corneal grafts in non-human primates. Xenotransplantation, 2017; 24: e12298 https://doi.org/10.1111/

16. Watanabe $H$, Sahara $H$, Nomura $S$, et al. Histologically proven survival of porcine lung xenografts in baboons for up to 10 days using double transgenic hCD47/hCD55 GalT-KO donors. Xenotransplantation. 2017;24: e12328. https://doi.org/10.1111/xen.1232853.

17. Kim S, Higginbotham LB, Mathews DV, et al. CD4 depletion is necessary and sufficient for long-term pig-tononhuman primate renal xenotransplant survival. Xenotransplantation. 2017;24:e12328.

18. Mueller NJ, Fishman JA. Herpesvirus infections in xenotransplantation: pathogenesis and approaches. Xenotransplantation. 2004;11(6):486-90.

19. Denner J. Xenotransplantation and porcine cytomegalovirus. Xenotransplantation. 2015;22:329-35.

20. Widén F. Hepatitis E as a Zoonosis. Adv Exp Med Biol. 2016;948:61-71.

21. Denner J. Xenotransplantation and Hepatitis E virus. Xenotransplantation. 2015;22(3):167-73.

22. Denner J, Mueller NJ. Preventing transfer of infectious agents. Int J Surg. 2015;23:306-11.

23. Denner J, Mankertz A. Porcine circoviruses and xenotransplantation. Viruses. 2017;20:9(4)

24. Lunney JK, Fang Y, Ladinig A, Chen N, Li Y, Rowland B, Porcine Reproductive RGJ. Respiratory syndrome virus (PRRSV): pathogenesis and interaction with the immune system. Annu Rev Anim Biosci. 2016:4:129-54.

25. Clayton BA. Nipah virus: transmission of a zoonotic paramyxovirus. Curr Opin Virol. 2017;22:97-104.

26. Denner J, Tönjes RR. Infection barriers to successful xenotransplantation focusing on porcine endogenous retroviruses. Clin Microbiol Rev. 2012;25(2): 318-43.
27. Denner J. Why was PERV not transmitted during preclinical and clinical xenotransplantation trials and after inoculation of animals? Retrovirology. 2018;15(1):28.

28. Yang L, Güell M, Niu D, George H, Lesha E, Grishin D, Aach J, Shrock E, Xu W, Poci J, Cortazio R, Wilkinson RA, Fishman JA, Church G. Genome-wide inactivation of porcine endogenous retroviruses (PERVs). Science. 2015; 350(6264):1101-4

29. Niu D, Wei HJ, Lin L, George $H$, Wang $T$, Lee $H$, Zhao HY, Wang $Y$, Kan $Y$, Shrock E, Lesha E, Wang G, Luo Y, Qing Y, Jiao D, Zhao H, Zhou X, Wang S, Wei H, Güell M, Church GM, Yang L. Inactivation of porcine endogenous retrovirus in pigs using CRISPR-Cas9. Science. 2017;357(6357):1303-7.

30. Denner J. Paving the path toward porcine organs for transplantation. N Engl J Med. 2017;377(19):1891-3.

31. Gu W, Zeng N, Zhou L, Ge X, Gu X, Yang H. Genomic organization and molecular characterization of porcine cytomegalovirus. Virology. 2014;460461:165-72

32. Edington N. Porcine cytomegalovirus. Dis Swine. 1986;138:330-6.

33. Edington $N$, Watt RG, Plowright W. Experimental transplacental transmission of porcine cytomegalovirus. J Hyg (Lond). 1977;78:243-51.

34. Edington N, Broad S, Wrathall AE, Done JT. Superinfection with porcine cytomegalovirus initiate infection. Vet Microbiol. 1988;16:189-93.

35. Widen F, Goltz M, Wittenbrink N, Ehlers B, Banks M, Belak S. Identification and sequence analysis of the glycoprotein $B$ gene of porcine cytomegalovirus. Virus Genes. 2001;23(3):339-46.

36. Goltz M, Widen F, Banks M, Belak S, Ehlers B. Characterization of the DNA polymerase loci of porcine cytomegalovirus from diverse geographical origins. Virus Genes. 2000;21:249-55.

37. Griffiths P, Baraniak I, Reeves M. The pathogenesis of human cytomegalovirus. J Pathol. 2015;235(2):288-97.

38. Rubin $\mathrm{RH}$. Impact of cytomegalovirus infection on organ transplant recipients. Rev Infect Dis. 1990;12(Suppl 7):754-66.

39. Atabani SF, Smith C, Atkinson C, Aldridge RW, Rodriguez-Perálvarez M, Rolando N, Harber M, Jones G, O'Riordan A, Burroughs AK, Thorburn D, O'Beirne J, Milne RS, Emery VC, Griffiths PD, et al. Cytomegalovirus replication kinetics in solid organ transplant recipients managed by preemptive therapy. Am J Transpl. 2012;12:2457-64.

40. Fishman JA, Rubin $\mathrm{RH}$. Infection in organ-transplant recipients. $\mathrm{N}$ Engl J Med. 1998;338(24):1741-51.

41. Ison MG, Fishman JA. Cytomegalovirus pneumonia in transplant recipients. Clin Chest Med. 2005;26(4):691-70.

42. Ljungman P. Cytomegalovirus pneumonia: presentation, diagnosis, and treatment. Semin Respir Infect. 1995;10(4):209-15.

43. Tiula $E$, Leinikki P. Fatal cytomegalovirus infection in a previously healthy boy with myocarditis and consumption coagulopathy as presenting signs. Scand J Infect Dis. 1972;4(1):57-60.

44. Jeejeebhoy FM, Zaltzman JS. Thrombotic microangiopathy in association with cytomegalovirus infection in a renal transplant patient: a new treatment strategy. Transplantation. 1998;65(12):1645-8.

45. Avdic S, McSharry BP, Steain M, Poole E, Sinclair J, Abendroth A, Slobedman B. Human cytomegalovirus-encoded human Interleukin-10 (IL-10) homolog amplifies its immunomodulatory potential by upregulating human IL-10 in monocytes. J Virol. 2016;90(8):3819-27.

46. Young VP, Mariano MC, Tu CC, Allaire KM, Avdic S, Slobedman B, Spencer JV. Modulation of the host environment by human cytomegalovirus with viral interleukin 10 in peripheral blood. J Infect Dis. 2017;215(6):874-82.

47. Fiebig U, Holzer A, Ivanusic D, Plotzki E, Hengel H, Neipel F, Denner J. Antibody cross-reactivity between porcine cytomegalovirus (PCMV) and human Herpesvirus-6 (HHV-6). Viruses. 2017;9(11).

48. Pantry SN, Medveczky PG. Latency, integration, and reactivation of human Herpesvirus-6. Viruses. 2017;9(7):E194. https://doi.org/10.3390/v9070194.

49. Kumar D. Emerging viruses in transplantation. Curr Opin Infect Dis. 2010; 23(4):374-8.

50. Tesini BL, Epstein LG, Caserta MT. Clinical impact of primary infection with roseoloviruses. Curr Opin Virol. 2014;9:91-6.

51. Griffiths PD, Ait-Khaled M, Bearcroft CP, Clark DA, Quaglia A, Davies SE, Burroughs AK, Rolles K, Kidd IM, Knight SN, Noibi SM, Cope AV, Phillips AN, Emery VC. Human herpesviruses 6 and 7 as potential pathogens after liver transplant: prospective comparison with the effect of cytomegalovirus. J Med Virol. 1999;59(4):496-501.

52. Kidd IM, Clark DA, Sabin CA, Andrew D, Hassan-Walker AF, Sweny P, Griffiths $P D$, Emery VC. Prospective study of human betaherpesviruses after renal 
transplantation: association of human herpesvirus 7 and cytomegalovirus co-infection with cytomegalovirus disease and increased rejection. Transplantation. 2000;69(11):2400-4.

53. Caïola D, Karras A, Flandre P, Boutolleau D, Scieux C, Agut H, Legendre C, Gautheret-Dejean A. Confirmation of the low clinical effect of human herpesvirus- 6 and -7 infections after renal transplantation. J Med Virol. 2012;84(3):450-6.

54. Mueller NJ, Barth RN, Yamamoto S, Kitamura H, Patience C, Yamada K, Cooper DK, Sachs DH, Kaur A, Fishman JA. Activation of cytomegalovirus in pig-to-primate organ xenotransplantation. J Virol. 2002;76(10):4734-40.

55. Gollackner B, Mueller NJ, Houser S, Qawi I, Soizic D, Knosalla C, Buhler L, Dor FJ, Awwad M, Sachs DH, Cooper DK, Robson SC, Fishman JA. Porcine cytomegalovirus and coagulopathy in pig-to-primate xenotransplantation. Transplantation. 2003;75(11):1841-7.

56. Mueller NJ, Livingston C, Knosalla C, Barth RN, Yamamoto S, Gollackner B, Dor FJ, Buhler L, Sachs DH, Yamada K, Cooper DK, Fishman JA. Activation of porcine cytomegalovirus, but not porcine lymphotropic herpesvirus, in pigto-baboon xenotransplantation. J Infect Dis. 2004;189(9):1628-33.

57. Mueller NJ, Kuwaki K, Dor FJ, Knosalla C, Gollackner B, Wilkinson RA, Sachs DH, Cooper DK, Fishman JA. Reduction of consumptive coagulopathy using porcine cytomegalovirus-free cardiac porcine grafts in pig-to-primate xenotransplantation. Transplantation. 2004;78(10):1449-53.

58. Yamada K, Tasaki M, Sekijima M, Wilkinson RA, Villani V, Moran SG, Cormack TA, Hanekamp IM, Hawley RJ, Arn JS, Fishman JA, Shimizu A, Sachs DH. Porcine cytomegalovirus infection is associated with early rejection of kidney grafts in a pig to baboon xenotransplantation model. Transplantation. 2014;98(4):411-8.

59. Sekijima M, Waki S, Sahara H, Tasaki M, Wilkinson RA, Villani V, Shimatsu Y, Nakano K, Matsunari H, Nagashima H, Fishman JA, Shimizu A, Yamada K. Results of life-supporting galactosyltransferase knockout kidneys in cynomolgus monkeys using two different sources of galactosyltransferase knockout swine. Transplantation. 2014;98:419-26.

60. Shah JA, Patel MS, Elias N, Navarro-Alvarez N, Rosales I, Wilkinson RA, Louras NJ, Hertl M, Fishman JA, Colvin RB, Cosimi AB, Markmann JF, Sachs DH, Vagefi PA. Prolonged survival following pig-to-primate liver xenotransplantation utilizing exogenous coagulation factors and Costimulation blockade. Am J Transplant. 2017;17(8):2178-85.

61. Abicht JM, Mayr TA, Reichart B, Plotzki E, Güthoff S, Falkenau A, Kind A, Denner J. Hepatic failure after pig heart transplantation into a baboon: no involvement of porcine hepatitis E virus. Ann Transplant. 2016;21:12-6.

62. Morozov VA, Abicht JM, Reichart B, Mayr T, Guethoff S, Denner J. Active replication of porcine cytomegalovirus (PCMV) following transplantation of a pig heart into a baboon despite undetected virus in the donor pig. Ann Virol Res. 2016;2(3):1018.

63. Fiebig U, Abicht JM, Mayr T, Längin M, Bähr A, Guethoff S, Falkenau A, Wolf E, Reichart B, Shibahara T, Denner J. Distribution of porcine cytomegalovirus in infected donor pigs and in baboon recipients of pig heart transplantation. Viruses. 2018;10(2).

64. Whitteker $\mathrm{L}$, Dudani AK, Tackaberry ES. Human fibroblasts are permissive for porcine cytomegalovirus in vitro. Transplantation. 2008;86(1):155-62.

65. Tucker AW, Galbraith D, McEwan P, Onions D. Evaluation of porcine cytomegalovirus as a potential zoonotic agent in xenotransplantation. Transplant Proc. 1999;31(1-2):915.

66. Ostermann E, Pawletko K, Indenbirken D, Schumacher U, Brune W. Stepwise adaptation of murine cytomegalovirus to cells of a foreign host for identification of host range determinants. Med Microbiol Immunol. 2015;204(3):461-9.

67. Jurak I, Brune W. Induction of apoptosis limits cytomegalovirus cross-species infection. EMBO J. 2006;25(11):2634-42.

68. van Den Pol AN, Mocarski E, Saederup N, Vieira J, Meier TJ. Cytomegalovirus cell tropism, replication, and gene transfer in brain. J Neurosci. 1999;19(24): 10948-65.

69. Michaels MG, Alcendor DJ, St George K, Rinaldo CR Jr, Ehrlich GD, Becich MJ, Hayward GS. Distinguishing baboon cytomegalovirus from human cytomegalovirus: importance for xenotransplantation. J Infect Dis. 1997;176(6):1476-83.

70. Michaels MG, Jenkins FJ, St George K, Nalesnik MA, Starzl TE, Rinaldo CR Jr. Detection of infectious baboon cytomegalovirus after baboon-to-human liver xenotransplantation. J Virol. 2001;75(6):2825-8.

71. Degré M, Ranneberg-Nilsen T, Beck S, Rollag H, Fiane AE. Human cytomegalovirus productively infects porcine endothelial cells in vitro. Transplantation. 2001;72(7):1334-7.

72. Fishman JA. Infectious disease risks in xenotransplantation. Am J Transplant. 2018. https://doi.org/10.1111/ajt.14725.
73. Bühler L, Yamada K, Kitamura H, Alwayn IP, Basker M, Appel JZ 3rd, Colvin RB, White-Scharf ME, Sachs DH, Robson SC, Awwad M, Cooper DK. Pig kidney transplantation in baboons: anti-gal(alpha)1-3Gal lgM alone is associated with acute humoral xenograft rejection and disseminated intravascular coagulation. Transplantation. 2001;72(11):1743-52.

74. lerino FL, Kozlowski T, Siegel JB, Shimizu A, Colvin RB, Banerjee PT, Cooper DK, Cosimi AB, Bach FH, Sachs DH, Robson SC. Disseminated intravascular coagulation in association with the delayed rejection of pig-to-baboon renal xenografts. Transplantation. 1998:66(11):1439-50.

75. Bühler L, Basker M, Alwayn IP, Goepfert C, Kitamura H, Kawai T, Gojo S, Kozlowski T, lerino FL, Awwad M, Sachs DH, Sackstein R, Robson SC, Cooper DK. Coagulation and thrombotic disorders associated with pig organ and hematopoietic cell transplantation in nonhuman primates. Transplantation. 2000;70(9):1323-31.

76. Sutherland MR, Raynor CM, Leenknegt H, Wright JF, Pryzdial EL. Coagulation initiated on herpesviruses. Proc Natl Acad Sci U S A. 1997;94(25):13510-4.

77. Sutherland MR, Friedman HM, Pryzdial EL. Herpes simplex virus type 1encoded glycoprotein C enhances coagulation factor VIla activity on the virus. Thromb Haemost. 2004;92(5):947-55.

78. Sedmak DD, Knight DA, Vook NC, Waldman JW. Divergent patterns of ELAM-1, ICAM-1, and VCAM-1 expression on cytomegalovirus-infected endothelial cells. Transplantation. 1994:58(12):1379-85.

79. Liu X, Liao S, Zhu L, Xu Z, Zhou Y. Molecular epidemiology of porcine cytomegalovirus (PCMV) in Sichuan province, China: 2010-2013. PLoS One. 2013;8:e64648

80. Liu X, Xu Z, Zhu L, Liao S, Guo W. Transcriptome analysis of porcine thymus following porcine cytomegalovirus infection. PLoS One. 2014;9(11):e113921.

81. Liu X, Liao S, Xu Z, Zhu L, Yang F, Guo W. Identification and Analysis of the porcine MicroRNA in porcine cytomegalovirus-infected macrophages using deep sequencing. PLoS One. 2016;11(3):e0150971.

82. Fishman JA, Sachs DH, Yamada K, Wilkinson RA. Absence of interaction between porcine endogenous retrovirus and porcine cytomegalovirus in pig-to-baboon renal xenotransplantation in vivo. Xenotransplantation. 2018; e12395. https://doi.org/10.1111/xen.12395. Epub ahead of print.

83. Guedes MI, Risdahl JM, Wiseman B, Molitor TW. Reactivation of porcine cytomegalovirus through allogeneic stimulation. J Clin Microbiol. 2004;42(4): 1756-8.

84. Wilson CA, Wong S, Muller J, Davidson CE, Rose TM, Burd P. Type C retrovirus released from porcine primary peripheral blood mononuclear cells infects human cells. J Virol. 1998;72(4):3082-7.

85. Tacke SJ, Specke V, Denner J. Differences in release and determination of subtype of porcine endogenous retroviruses produced by stimulated normal pig blood cells. Intervirology. 2003;46(1):17-24.

86. Dieckhoff B, Kessler B, Jobst D, Kues W, Petersen B, Pfeifer A, Kurth R, Niemann H, Wolf E, Denner J. Distribution and expression of porcine endogenous retroviruses in multi-transgenic pigs generated for xenotransplantation. Xenotransplantation. 2009;16(2):64-73.

87. Mueller NJ, Kuwaki K, Knosalla C, Dor FJ, Gollackner B, Wilkinson RA, Arn S, Sachs DH, Cooper DK, Fishman JA. Early weaning of piglets fails to exclude porcine lymphotropic herpesvirus. Xenotransplantation. 2005;12(1):59-62.

88. Egerer S, Fiebig U, Kessler B, Zakhartchenko V, Kurome M, Reichart B, Kupatt C, Klymiuk N, Wolf E, Denner J, Bähr A. Early weaning completely eliminates porcine cytomegalovirus from a newly established pig donor facility for xenotransplantation. Xenotransplantation. 2018 Jul;25(4):e12449.

89. Fryer JF, Griffiths PD, Emery VC, Clark DA. Susceptibility of porcine cytomegalovirus to antiviral drugs. J Antimicrob Chemother. 2004;53(6):975-80.

90. Mueller NJ, Sulling K, Gollackner B, Yamamoto S, Knosalla C, Wilkinson RA, Kaur A, Sachs DH, Yamada K, Cooper DK, Patience C, Fishman JA. Reduced efficacy of ganciclovir against porcine and baboon cytomegalovirus in pigto-baboon xenotransplantation. Am J Transplant. 2003;3(9):1057-64.

91. Schleiss MR. Developing a vaccine against congenital cytomegalovirus (CMV) infection: what have we learned from animal models? Where should we go next? Future Virol. 2013;8(12):1161-82. 